\title{
Accounting Benefits of ERP Systems across the Different Manufacturing Industries of SMEs
}

\author{
Spyridon Goumas' ${ }^{1}$ Dimitris Charamis ${ }^{2}$, Efthalia Tabouratzi ${ }^{3,4^{*}}$ \\ ${ }^{1}$ Department of Accounting and Finance, Piraeus University of Applied Sciences, Piraeus, Greece \\ ${ }^{2}$ Department of Business Administration, University of Patras, Patras, Greece \\ ${ }^{3}$ Department of Accounting and Finance, Technological Educational Institute of Crete, Crete, Greece \\ ${ }^{4}$ Hellenic Open University, Patras, Greece \\ Email:sgoum@teipir.gr, dcharamis@gmail.com, ^tamthal@staff.teicrete.gr
}

How to cite this paper: Goumas, S., Charamis, D. and Tabouratzi, E. (2018) Accounting Benefits of ERP Systems across the Different Manufacturing Industries of SMEs. Theoretical Economics Letters, 8, 1232-1246. https://doi.org/10.4236/tel.2018.86081

Received: February 26, 2018

Accepted: April 20, 2018

Published: April 23, 2018

Copyright $\odot 2018$ by authors and Scientific Research Publishing Inc. This work is licensed under the Creative Commons Attribution International License (CC BY 4.0).

http://creativecommons.org/licenses/by/4.0/

\begin{abstract}
As a result of the ongoing economic crisis and the international market competition, Greek SMEs, particularly the ones focusing in manufacture and production, need to stay profitable by increasing efficiency, while reducing operational costs. Information collected, stored and processed by ERP systems help SMEs to reduce uncertainty, and improve operations and managerial decision-making. Manufacture SMEs could benefit from the implementation of an ERP system, as there are many aspects in the business to consider. However, most decisions are based on financial information. The current study explores the accounting benefits of implementing ERPs on manufacture SMEs, from an accounting standpoint. Findings demonstrate the difference in importance of the various accounting benefits within the different manufacturing categories.
\end{abstract}

\section{Keywords}

ERP Systems, Accounting Benefits, Manufacturing Sector, Manufacturing Industries, SMEs

\section{Introduction}

In order for businesses to be successful several kinds of data need to be collected, such as information from all activities regarding the revenue cycle, the expenditure cycle and the human resource cycle [1]. Traditionally, AIS referred to as a transaction processing system solely focusing on financial data and accounting transactions. However, for a company to perform and managerial decisions to be made, more information is needed, thus, enterprise resource planning (ERP) 
systems are essential. These systems integrate all aspects of a company's operations, in order to coordinate and manage resources, as well as financial and business activities. Consequently, ERP systems provide the information to managers and external parties who appraise the company [1]. Nevertheless, companies set different goals and have dissimilar short and long-term objectives. In this manner, the ERP system they choose has to incorporate all the functions that matter to the business.

In the Greek context, SMEs are the pillar of entrepreneurship of the economy at a national level, with rates ranging between $99.8 \%$ and $99.9 \%$ of the total number of businesses [2]. This is one of the highest densities of SMEs relative to the population. Despite of the evidence that ERP systems have a significant impact on SMEs, these integrated systems may seem unnecessary or unapproachable due to the size of some of the businesses and the cost of such a system [3]. However, SMEs are the companies that suffer the most during an economic crisis as there is a general lack of efficiency when companies perform without these tools. Hence, the use of ERP systems could maintain or restore efficiency at a corporate level and helps with the organization of all financial data concerning the business. The current study explores the accounting benefits of implementing ERPs on manufacture SMEs, from an accounting standpoint. Findings demonstrate the difference in importance of the various accounting benefits within the different manufacturing categories.

\section{Literature Review}

\subsection{ERP Systems' Benefits}

Firms adopt IT to improve business performance and acquire a competitive advantage in the national and international market [3]. Globalization increases the demand for a more organized and operational homogeneity of processes, and by examining businesses' operations, the similarities and common needs across manufacture companies are easily observed. Companies are constantly setting objectives, which they compare against corporate performance. Through strategic control for long-term, and task control for short-term performance, information is collected and analyzed for managerial purposes. ERP systems pave the way for SMEs towards standardization of operations and a more centralized management [4]. These systems also facilitate the collection and analysis of both financial and non-financial information across various departments, and consequently help management with decision-making and achievement of goals.

As Davenport [5] notes, the use of Accounting Information Systems (AIS), and more specifically ERP systems, is a very important development in production management of SMEs. ERP systems integrate multiple enterprise functions that were previously stored in autonomous software units and are shared with the different departments within a firm in a unified manner. Through their multidimensional and complex analytical power, they process the information (expenses, materials, manufacturing, orders, revenues, etc.) and produce useful 
managerial and accounting information in real time. ERP systems also promote homogeneity in the information reported (Garcia \& Garcia-Garcia 2010), which reduce ambiguities and confusion for managers and accountants. ERP systems encourage the use of all available resources, and coordinate procedures in the most efficient way for the company [6] [7]. Moreover, internal control weaknesses (ICW) that could prove risky for investment decisions are minimized with ERP use [8] [9].

Having formalized and standardized communication processes at all times, eases the collaboration within the company, and improves relations with suppliers and customers [4]. The analytics generated from ERP systems, provide better insights and increase productivity, as reliable and up-to-date information contributes in more effective and efficient activity planning and reporting, which also increases general performance. Further, Teittinen, Pellinen and Järvenpää [10] observe that even though companies do not take advantage of the full potential of ERP systems, due to ignorance and lack of IT skills, the very basic financial accounting processes have a significant impact on managerial decisions. Additionally, ERP systems have the ability to process additional, non financial information, which reflect positively on the company. Focusing on internal business processes and what is needed at all stages of production leads to overall productivity. This is because processes are well-organized and all resources are used efficiently [11], creating a competitive advantage, and also enabling future business ventures. Moreover, as a result of the high competition in the market, companies must understand clients' needs in order to keep them satisfied [12]. Clients' main concern is the design, high quality, timely delivery, service levels and most importantly price [11]. Through ERP systems, all the above can be stored, managed and used as key performance indicators for overall financial performance. Thus, the financial measures used for reporting, such as sales growth, are resulting from the high quality of processes [13].

Consequently, ERP systems create value to the company, by providing efficiency of accounting processes [4] [14] and by creating unique capabilities positively affecting performance [15]. While the percentage of SMEs using ERP is low compared to larger companies, mainly due to budgetary restrictions, SMEs face higher financial risks by not using such systems [3] [16] [17]. Hence, the main motivations for implementing an ERP according to Spathis and Constantinides [18] can be classified under management and accounting, and are presented in Table 1.

\subsection{Accounting Benefits and ERP Use}

Following Sutton's [6] call for additional empirical evidence on the accounting advantages deriving from the use of ERP systems in business, many academics have tackled the matter, by recognizing and examining these benefits in different contexts.

In fast developing and more advanced marketplaces, companies face an increased number of accounting processes, and have therefore assimilated into a 
Table 1. Motivations leading to the adoption of ERP implementation.

\begin{tabular}{cc}
\hline Managerial motivations & Accounting motivations \\
\hline Integration of all corporate applications & Flexibility of generating information \\
Real time access of information & Integration of all accounting information \\
Information facilitating decision-making & Convenient and timely closure of annual reports \\
\hline
\end{tabular}

digitalized accounting era [19]. According to Biddle et al. [20], low quality of financial reporting can lead to unsuitable managerial decisions that could have a negative impact on the company. Therefore, for investment efficiency accuracy in financial reporting is essential [8]. Timely profitability analysis and accurate financial reporting for managers are required [21], and ERP systems deal with standardized procedures to achieve this real-time and efficient delivery of financial information [4]. In the manufacture sector, processes are more complicated regarding the use of ERP systems, as companies deal with a larger volume of data [7]. Therefore, financial accounting through ERP systems is believed to be more accurate, as it is solely based on standard information imputed in the system [22]. ERP use enhances accounting tasks by significantly decreasing reporting lags [23], and producing more accurate statements of accounts and other financial reports [24]. Moreover, the volume of data that manufacture companies have to deal with (warehousing, sales, production etc.), becomes more manageable with ERP systems as there is no need for multiple data entry [25].

In manufacturing companies, ERP systems contribute more to the overall performance if used along the production stage and if all daily business procedures are recorded [15]. Then, analytics become more detailed, and expenditures can be correctly allocated to certain activities that could enhance transactional efficiency and consequently create an over the competition [26]. Furthermore the timely transmission of accounting information achieved by ERP use creates a continuous reporting and continuous auditing corporate environment [6] [27] ERP systems also decrease the time for accounting procedures, such as financial reports, as these are generated in an automated manner. This gives quality time to accountants, who now spend less time for closing entries and books, and decision-makers to analyze these reports thoroughly [6]. This automated reporting gives top management comparable and precise financial material, which proves to be essential when there are more than one production plants. Contrarily, cost and profitability analysis depend on information regarding the production line, which in the real manufacturing environment are occasionally doubtful and not entirely trusted by management [10]. Therefore, for ERP systems to be trusted, all steps need to be accurately included in order to avoid inconsistencies due to human error. Flexibility is also essential, as under real circumstances disruptions may occur.

To sum up, it is clear that ERP systems contribute to the amelioration and efficiency of accounting and financial processes, and businesses benefit from 
them. However, as it is difficult to quantify both the information costs and the value of information produced, businesses need to evaluate the information generation cost, and make sure that it does not exceed the benefits [1].

\section{Methodology}

This paper is looking into the accounting benefits of ERP systems on manufacturing companies. A quantitative approach was selected for this study, in order to identify the advantages linked to accounting, deriving from the implementation of such a system on various types of manufacturing companies.

\subsection{Sampling Method and Procedure}

The sampling method used to conduct the current study was purposive, and more specifically homogeneous, as it focuses on one subgroup which provides in-depth focus (accountants and manufacturing companies) [28].

Six major ERP software providers selected from conducting secondary online research (three national and three international) were first contacted, and lists of their clientele in Greece were requested. Then further secondary research facilitated the division of the companies into sectors, from which 413 production companies using ERP systems for more than a year up to seven years were found. One year was used as a baseline, as the findings of Teittinen, Pellinen and Järvenpää [10] indicated that after the first year of use, stability and improvement in performance were observed.

All questionnaires were designed on Google Forms, which is compatible with most operating systems. The production companies were informed via e-mail in advance, to inform the companies about the study, followed by the online questionnaire. By choosing an online questionnaire, the rejection of responses due to insufficient content was minimized, as all fields were required. The landing page of the hyperlink included information about the purpose of the study, which was introduced as "evaluation of ERP systems" instead of "benefits of ERP systems", to avoid participants' response bias.

The study consisted of four sections. The first one included three screening questions (whether the participant's current role at the company was in accounting, the ERP system the company used included an accounting module, and whether the ERP system was use for more than a year and up to seven years), even though there were clear instructions on how to complete the questionnaire. In the following section participants were asked to state their demographic information, such as gender, age, years of accounting experience and years at current position, some company details, such as industry classification ( $3^{\text {rd }}$ revision) [29] and number of employees. Section three focused on the ERP system; participants had to select one of the six ERP providers and the additional modules on the system had to be checked. The final question on that section was dedicated to the accounting benefits of ERP systems where 19 concepts had to be rated on 7-point Likert scales [28]. 


\subsection{Measures}

The last section focused on the ERP systems' accounting benefits. The list consisting of 19 items was generated by ERP benefits identified by previous researches. The initial benefits list was created by Deloitte Consulting [30]. The addition of more and classification of those benefits into five categories (IT infrastructure, managerial, operational, organizational and strategic) was done by Shang, S. and Seddon, P. [31]. Additional intangible benefits were added to it by O'Leary [32] and other researchers [7] [33]. However, from Kanellou and Spathis' [7] benefits' list, the generic benefits added to their final list were not included, as those aspects were identified and used on researches, prior to the development of more specific benefit lists used on this study. The items were sorted alphabetically and rated on a 7-point Likert agreement scale, where 1 indicated "Strongly disagree" and 7 indicated "Strongly agree" [34].

\subsection{Pilot Study}

A pilot study was conducted prior to the main study just for quality purposes. Since the measures that developed in English would be tested on a population where English was not their first language (Greece), misunderstandings in the communication and interpretation of the questionnaire had to be avoided. Therefore, during the design process, back-translation with a native Greek speaker and an English one was required [28]. Following that procedure, accountants from 20 companies of various sectors participated in the pilot study. The sector was not important at this stage, as the pilot study was conducted for quality purposes as mentioned before. The results from the pilot study lead to minor changes in grammar and syntax.

\subsection{Sample}

The online, self-completed questionnaire of the main study was administered to all 413 production companies, but only 205 were answered during the 12 week timeframe (11 September 2017-10 December 2018). From those questionnaires only 182 were used, as some questionnaires got rejected due to extreme responding and screening questions. That represents a $44.1 \%$ response rate, which is acceptable ( $>40 \%)$ since it was addressed to companies [35]. Appendix A demonstrates in detail the demographic information of the sample.

\section{Results}

The results obtained from the data of the study regarding the accounting benefits of ERP systems are presented in Table 2.

Noticing the total mean scores for each of the accounting benefits, differences are apparent. Regarding the IT accounting benefits (ERP processes results easier, gathers data easier and more quickly, reduction in transaction entry and accounting department communicates easier), the first four items scored relatively high, and were consistent across almost all manufacturing industries. Lower mean scores in this IT accounting benefit category were observed for the basic 
Table 2. Means of ERP accounting benefits for each industry.

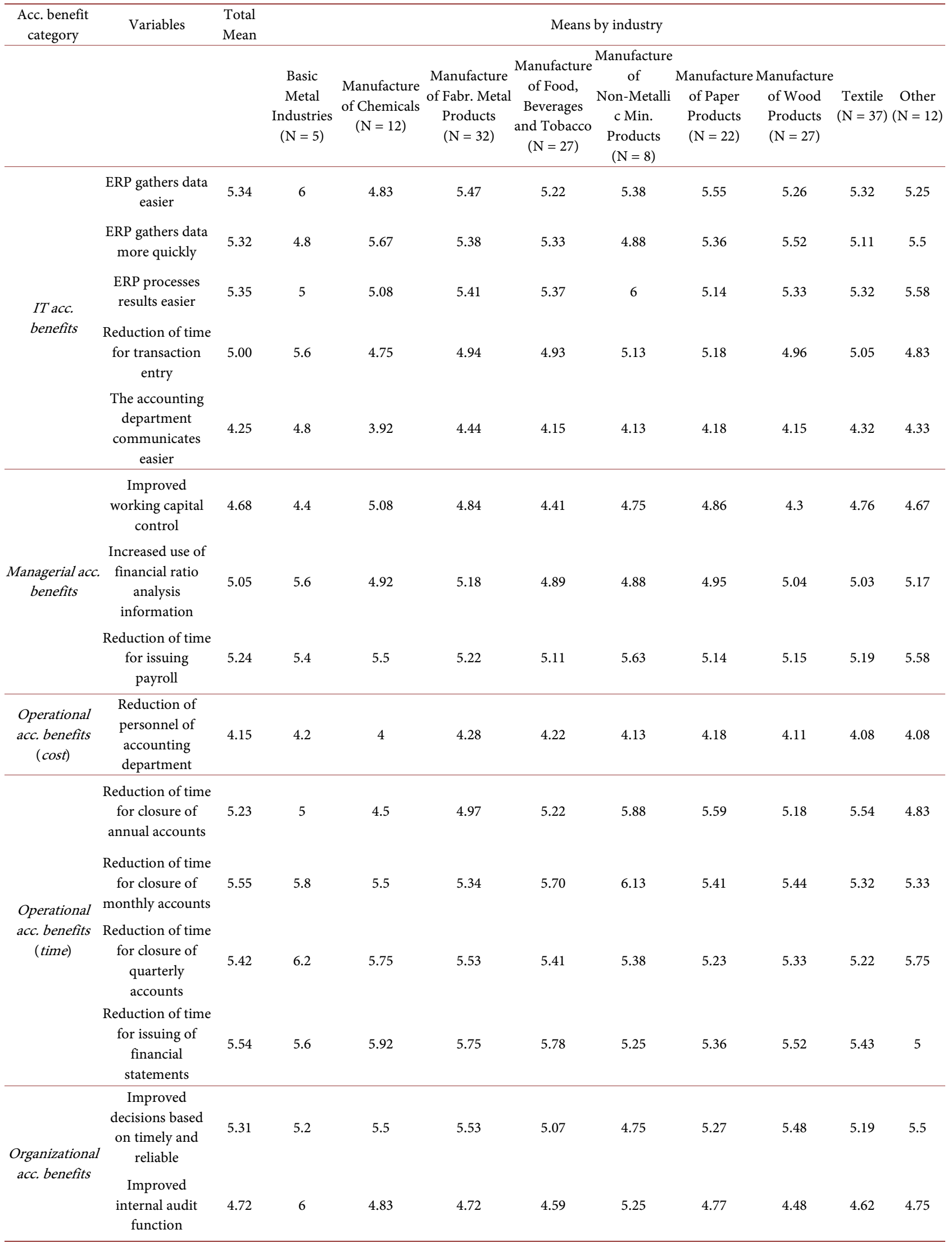




\section{Continued}

\begin{tabular}{|c|c|c|c|c|c|c|c|c|c|c|c|}
\hline \multirow{4}{*}{$\begin{array}{l}\text { Organizational } \\
\text { acc. benefits }\end{array}$} & $\begin{array}{l}\text { Improved quality } \\
\text { of reports } \\
\text { statements of } \\
\text { account }\end{array}$ & 5.71 & 5.6 & 6.08 & 5.59 & 5.37 & 6 & 5.95 & 5.59 & 5.73 & 6 \\
\hline & $\begin{array}{l}\text { Increased } \\
\text { flexibility in } \\
\text { information } \\
\text { generation }\end{array}$ & 5.18 & 5 & 5.25 & 5.19 & 5.03 & 5.63 & 4.95 & 5.22 & 5.19 & 5.5 \\
\hline & $\begin{array}{l}\text { Increased } \\
\text { integration of } \\
\text { accounting } \\
\text { applications }\end{array}$ & 5.19 & 4.6 & 5.33 & 5.28 & 5.33 & 5.38 & 5.05 & 5.19 & 5.11 & 5.17 \\
\hline & $\begin{array}{l}\text { ERP is user } \\
\text { friendly with } \\
\text { other } \\
\text { departments }\end{array}$ & 5.15 & 5.6 & 5.17 & 5.22 & 5.07 & 5.13 & 5.05 & 5.19 & 5 & 5.58 \\
\hline Total Mear & of benefits & & 5.28 & 5.14 & 5.18 & 5.06 & 5.24 & 5.11 & 5.08 & 5.18 & 5.08 \\
\hline
\end{tabular}

metal industries (Mean $=4.8$ ), and manufacture of non-metallic mineral industries $($ Mean $=4.88)$ for the "ERP gathers data more quickly" benefit, and for manufacture of chemicals industries (Mean $=4.83$ ) regarding the easiness of gathering data. "The acc. department communicates easier" scored poorly across all industries obtaining the second lowest overall mean score (Mean $=4.25)$.

With regard to managerial accounting benefits "reduction of time issuing payroll", came $7^{\text {th }}$ overall, with a total mean score of 5.24 , and $\mathrm{SD}=0.52$. The other two items of this group of benefits, scored a bit higher ("improved working capital control" Mean $=4.68, \mathrm{SD}=1.5$ and "increased use of financial ratio analysis" Mean $=5.05, \mathrm{SD}=0.72$ ).

The cost aspect of the operational accounting benefits, focusing on the "reduction of personnel of accounting department scored the lowest from all the ERP accounting benefits on the list. This item's total mean score was 4.15 , and means within industries ranged from 4 to 4.28 .

On the subject of the operational accounting benefits regarding time, all 4 values received high scores; 5.55, 5.54, 5.42 and 5.23, for reduction of time closure of monthly accounts, for issuing financial statements, for closure of quarterly accounts and closure of annual accounts respectively. The mean scores are pretty consistent across all industries, with values varying between 4.5 and 6.2. In basic metal industries and non-metallic industries we notice high values for "closure of quarterly accounts" (Mean = 6.2) and for "closure of monthly accounts" (Mean $=6.13$ ) respectively. Reduction of time for closing annual accounts was the lowest in the chemical industry with mean score 4.5 , with the total mean of all industries being 5.23 for the specific benefit.

Lastly, with respect to organizational accounting benefits, five items out of the six, were rated obtained high results, with "Improved quality of reports statements of account" achieving the highest overall score for all industries (Mean = 
$5.71, \mathrm{SD}=0.49$ ). On the specific group of organizational accounting benefits "improved decisions based on timely and reliable information" scored a total mean score of 5.31, with its lowest value being in the manufacture of non-metallic industries. Another low score was identified for "increased integration of accounting applications" (Mean $=4.6$ ), compared to the total mean of that benefit (total mean $=5.19$ ). Finally, "improved internal audit function" had the lowest total mean of the group (4.72), however, basic metal industries scored a mean score of 6 .

\section{Conclusions}

The main purpose of this study was to assess the importance of the different accounting benefits deriving from ERP use on the manufacturing sector in general, as well as on an industry level.

Findings revealed that organizational accounting benefits (Mean $=5.21)$ and IT accounting benefits (Mean $=5.05$ ) performed better than the rest of the benefit groups. The highest score was obtained for the item concerning the quality of the reports and statements of account. This finding was in line with the literature, as it was stressed how the standardized and accurate ERP outputs of accounting information [4] [22] help businesses and improved decision-making [6]. Similarly, an item concerning the reduction of time issuing payroll scored highly on the managerial accounting benefits. Here, it is observed that reduction of time for accounting processes is significantly reduced through ERP use, and this is recognized by all manufacturing industries.

However, even though companies use ERP systems, Teittinen, Pellinen and Järvenpää [10] observe that companies do not utilize the full potential of ERP systems. This observation may justify the fact that benefits regarding managerial accounting, such as improved working capital control and increased use of financial ratio analysis, scored poorly and consistently across all industries.

To sum up, it is evident that ERP systems have accounting benefits that are to the companies' advantage, as financial processes are performed in a timely, efficient and standardized manner. However, the impact of each benefit is different on each manufacturing SME, as the needs across industries vary. In the Greek SME context, ERP use seems to have an effect on businesses, however, there are inconsistencies that could be linked to certain factors. These are primarily the cost of a customized ERP system, and the fact that maybe due to the small size of businesses, processes are based on past experience, rather than the efficient and timely accounting information produced. Also, the lack of IT expertise and inability or inessentiality may limit the information output that an ERP can provide.

The present study contributes to the literature as accounting benefits have not been examined in terms of the different industries within the manufacturing sector. This academic work could be the beginning of further investigation and analysis into the differences of ERP accounting benefits across manufacturing 
industries. The findings of the study could also be of interest of managers of manufacturing companies as well, as they do not rely on generic accounting benefits of ERP systems. Instead, the benefits derived from ERP systems are specific to the industry in which they operate. Further, these findings would also benefit ERP providers tailor their marketing messages when promoting ERP systems to different industries.

However, there were several limitations regarding the current study. First, the number of the manufacturing companies that participated was limited to only 182. This sample was not distributed evenly between each industry within the manufacturing sector, and there are industries with as little as 5 companies, therefore generalizations regarding the different ERP accounting benefits affecting each industry cannot be made. Further study could be conducted to compare the different manufacturing industries with larger and similar in size samples, so that more statistical analysis could be performed. Moreover, the study could be conducted again across larger manufacturing industries, whose financial information is disclosed, and thus ERP systems are more essential for the generation of financial information. Finally, as ERP systems are applicable and tailored on all kinds of businesses, researchers could even explore the accounting benefits deriving from ERP use, in the tertiary sector, which since it involves commerce and services the results would be more interesting.

\section{References}

[1] Romney, M.B. and Steinbart, P.J. (2014) Accounting Information Systems. Pearson Higher Ed.

[2] Fessas, T. and Iosifidis, T. (2017) SMEs in Greece-Contribution to the Economy, Development and Challenges. http://www.sev.org.gr/uploads/Documents/50669/SMEs_partA.PDF

[3] Johansson, B. and Sudzina, F. (2008) ERP Systems and Open Source: An Initial Review and Some Implications for SMEs. Journal of Enterprise Information Management, 21, 649-658. https://doi.org/10.1108/17410390810911230

[4] Granlund, M. (2011) Extending AIS Research to Management Accounting and Control Issues: A Research Note. International Journal of Accounting Information Systems, 12, 3-19. https://doi.org/10.1016/j.accinf.2010.11.001

[5] Davenport, T.H. (1998) Putting the Enterprise into the Enterprise System. Harvard Business Review, 76, 121-131.

[6] Sutton, S. (2006) Enterprise Systems and the Re-Shaping of Accounting Systems: A Call for Research. International Journal of Accounting Information Systems, 7, 1-6. https://doi.org/10.1016/j.accinf.2006.02.002

[7] Kanellou, A. and Spathis, C. (2013) Accounting Benefits and Satisfaction in an ERP Environment. International Journal of Accounting Information Systems, 14, 209-234. https://doi.org/10.1016/j.accinf.2012.12.002

[8] Cheng, M., Dhaliwal, D. and Zhang, Y. (2013) Does Investment Efficiency Improve after the Disclosure of Material Weaknesses in Internal Control over Financial Reporting? Journal of Accounting and Economics, 56, 1-18.

[9] Tadesse, A. and Murthy, U. (2018) Nonprofessional Investor Perceptions of the Partial Remediation of IT and Non-IT Control Weaknesses: An Experimental In- 
vestigation. International Journal of Accounting Information Systems, 28, 14-30. https://doi.org/10.1016/j.accinf.2017.12.001

[10] Teittinen, H., Pellinen, J. and Järvenpää, M. (2013) ERP in Action-Challenges and Benefits for Management Control in SME Context. International Journal of Accounting Information Systems, 14, 278-296. https://doi.org/10.1016/j.accinf.2012.03.004

[11] Hoque, Z., Mia, L. and Alam, M. (2001) Market Competition, Computer Aided Manufacturing and Use of Multiple Performance Measures: An Empirical Study. The British Accounting Review, 33, 23-45. https://doi.org/10.1006/bare.2000.0149

[12] Weill, P. and Aral, S. (2006) Generating Premium Returns on Your IT Investments. MIT Sloan Management Review, 47, 39-48.

[13] Mohamad, A., Zainuddin, Y., Alam, N. and Kendall, G. (2017) Does Decentralized Decision Making Increase Company Performance through Its Information Technology Infrastructure Investment? International Journal of Accounting Information Systems, 27, 1-15. https://doi.org/10.1016/j.accinf.2017.09.001

[14] Klaus, H., Rosemann, M. and Guy, G.G. (2000) What Is ERP? Information Systems Frontiers, 2, 141-162. https://doi.org/10.1023/A:1026543906354

[15] Antero, M. and Riis, P.H. (2011) Strategic Management of Network Resources: A Case Study of an ERP Ecosystem. International Journal of Enterprise Information Systems, 7, 18-33. https://doi.org/10.4018/jeis.2011040102

[16] Bernroider, E. and Koch, S. (2001) ERP Selection Process in Midsize and Large Organizations. Business Process Management Journal, 7, 251-257.

https://doi.org/10.1108/14637150110392746

[17] Buonanno, G., Faverio, P., Pigni, F., Ravarini, A., Sciuto. D. and Tagliavin, M. (2005) Factors Affecting ERP System Adoption: A Comparative Analysis between SMEs and Large Companies. Journal of Enterprise Information Management, 18, 384-426. https://doi.org/10.1108/17410390510609572

[18] Spathis, C. and Constantinides, S. (2004) Enterprise Resource Planning Systems' Impact on Accounting Processes. Business Process Management Journal, 10, 234-247. https://doi.org/10.1108/14637150410530280

[19] Castells, M. and Himanen, P. (2002) The Information Society and the Welfare State: The Finnish Model (No. 250). Oxford University Press on Demand, Oxford. https://doi.org/10.1093/acprof:oso/9780199256990.001.0001

[20] Biddle, G.C., Hilary, G. and Verdi, R.S. (2009) How Does Financial Reporting Quality Relate to Investment Efficiency? Journal of Accounting and Economics, 48, 112-131. https://doi.org/10.1016/j.jacceco.2009.09.001

[21] Grabski, S. and Leech, S. (2007) Complementary Controls and ERP Implementation Success. International Journal of Accounting Information Systems, 8, 17-39. https://doi.org/10.1016/j.accinf.2006.12.002

[22] Colmenares, L. (2009) Benefits of ERP Systems for Accounting and Financial Management. In: Allied Academies International Conference. Academy of Management Information and Decision Sciences, Vol. 13, Jordan Whitney Enterprises, Inc., Tustin, 3.

[23] Brazel, J.F. and Dang, L. (2008) The Effect of ERP System Implementations on the Management of Earnings and Earnings Release Dates. Journal of Informationsystems, 22, 1-21. https://doi.org/10.2308/jis.2008.22.2.1

[24] Velcu, O. (2007) Exploring the Effects of ERP Systems on Organizational Performance: Evidence from Finnish Companies. Industrial Management \& Data Systems, 
107, 1316-1334. https://doi.org/10.1108/02635570710833983

[25] Chang, H.H. (2006) Technical and Management Perceptions of Enterprise Information System Importance, Implementation and Benefits. Information Systems Journal, 16, 263-292. https://doi.org/10.1111/j.1365-2575.2006.00217.x

[26] Ruivo, P., Oliveira, T. and Neto, M. (2014) Examine ERP Post-Implementation Stages of Use and Value: Empirical Evidence from Portuguese SMEs. International Journal of Accounting Information Systems, 15, 166-184. https://doi.org/10.1016/j.accinf.2014.01.002

[27] Stoel, D., Havelka, D. and Merhout, J. (2012) An Analysis of Attributes That Impact Information Technology Audit Quality: A Study of IT and Financial Audit Practitioners. International Journal of Accounting Information Systems, 13, 60-79. https://doi.org/10.1016/j.accinf.2011.11.001

[28] Saunders, M., Lewis, P. and Thornhill, A. (2016) Research Methods for Business Students. 7th Edition, Pearson, Harlow.

[29] ISIC (2017) Industry Classification. https://www.investmentmap.org/industry_classification.aspx

[30] Deloitte Consulting (1998) ERP's Second Wave: Maximizing the Value of ERP-Enabled Processes. Deloitte Consulting, New York.

[31] Shang, S. and Seddon, P. (2000) A Comprehensive Framework for Classifying the Benefits of ERP Systems. Americas Conference on Information Systems, Long Beach, 10-13 August 2000, 39.

[32] O’Leary, D.E. (2004) Enterprise Resource Planning (ERP) Systems: An Empirical Analysis of Benefits. Journal of Emerging Technologies in Accounting, 1, 63-72. https://doi.org/10.2308/jeta.2004.1.1.63

[33] Esteves, J. (2009) A Benefits Realization Road-Map Framework for ERP Usage in Small and Medium-Sized Enterprises. Journal of Enterprise Information Management, 22, 25-35. https://doi.org/10.1108/17410390910922804

[34] Vagias, W.M. (2006) Likert-Type Scale Response Anchors. Clemson International Institute for Tourism \& Research Development, Department of Parks, Recreation and Tourism Management, Clemson University, Clemson.

[35] Dillman, D.A. (2007) Mail and Internet Services: The Tailored Designed Method. 2nd Edition, John Wiley \& Sons, Inc., Hoboken. 


\section{Appendices}

Table A1. Descriptive analysis of sample $(\mathrm{N}=182)$.

\begin{tabular}{|c|c|c|c|}
\hline \multicolumn{2}{|r|}{ Variables } & \multirow{2}{*}{$\begin{array}{c}\text { Frequency } \\
154\end{array}$} & \multirow{2}{*}{$\begin{array}{c}\text { Percentage \% } \\
86.6\end{array}$} \\
\hline & Male & & \\
\hline 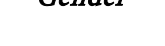 & Female & 28 & 15.4 \\
\hline \multirow{5}{*}{ Age } & $25-34$ & 22 & 12.1 \\
\hline & $35-44$ & 95 & 52.2 \\
\hline & $45-54$ & 46 & 25.3 \\
\hline & $55-64$ & 17 & 9.3 \\
\hline & $65+$ & 2 & 1.1 \\
\hline \multirow{5}{*}{$\begin{array}{c}\text { Accounting } \\
\text { experience } \\
\text { (years) }\end{array}$} & $0-5$ & 10 & 5.5 \\
\hline & $5-10$ & 34 & 18.7 \\
\hline & $10-15$ & 70 & 38.5 \\
\hline & $15-20$ & 52 & 28.6 \\
\hline & $20+$ & 16 & 8.8 \\
\hline \multirow{5}{*}{$\begin{array}{l}\text { Years in } \\
\text { current } \\
\text { position }\end{array}$} & $0-5$ & 113 & 62.1 \\
\hline & $5-10$ & 43 & 23.6 \\
\hline & $10-15$ & 21 & 11.5 \\
\hline & $15-20$ & 5 & 2.7 \\
\hline & $20+$ & - & - \\
\hline \multirow{9}{*}{ Industry } & Basic Metal Industries & 5 & 2.7 \\
\hline & $\begin{array}{c}\text { Manufacture of Chemicals and Chemical, Petroleum, } \\
\text { Coal, Rubber and Plastic Products }\end{array}$ & 12 & 6.6 \\
\hline & $\begin{array}{c}\text { Manufacture of Fabricated Metal Products, Machinery } \\
\text { and Equipment }\end{array}$ & 32 & 17.6 \\
\hline & Manufacture of Food, Beverages and Tobacco & 27 & 14.8 \\
\hline & $\begin{array}{c}\text { Manufacture of Non-Metallic Mineral Products, except } \\
\text { Products of Petroleum and Coal }\end{array}$ & 8 & 4.4 \\
\hline & $\begin{array}{c}\text { Manufacture of Paper and Paper Products, Printing and } \\
\text { Publishing }\end{array}$ & 22 & 12.1 \\
\hline & $\begin{array}{c}\text { Manufacture of Wood and Wood Products, Including } \\
\text { Furniture }\end{array}$ & 27 & 14.8 \\
\hline & Textile, Wearing Apparel and Leather Industries & 37 & 20.3 \\
\hline & Other Manufacturing Industries & 12 & 6.6 \\
\hline \multirow{6}{*}{$\begin{array}{l}\text { Number of } \\
\text { employees }\end{array}$} & $10-20$ & 19 & 10.4 \\
\hline & $20-50$ & 32 & 17.5 \\
\hline & $50-100$ & 59 & 32.4 \\
\hline & $100-150$ & 61 & 33.5 \\
\hline & $150-200$ & 5 & 2.7 \\
\hline & $200-250$ & 6 & 3.3 \\
\hline
\end{tabular}




\section{Continued}

\begin{tabular}{ccccccc}
\hline \multicolumn{5}{c}{ Frequency } & Percentage \% & \\
\multirow{4}{*}{ ERP } & Greek ERP 1 & 30 & 16.5 & & \\
providers & Greek ERP 2 & 22 & 12.1 & Greek ERPs & 90 & 49.5 \\
& Greek ERP 3 & 38 & 20.9 & & & \\
& Int. ERP 1 & 16 & 8.8 & & & \\
& Int. ERP 2 & 28 & 15.4 & Int. ERPs & 92 & 50.5 \\
& Int. ERP 3 & 48 & 26.4 & & & \\
\hline
\end{tabular}

Table A2. CLASS.

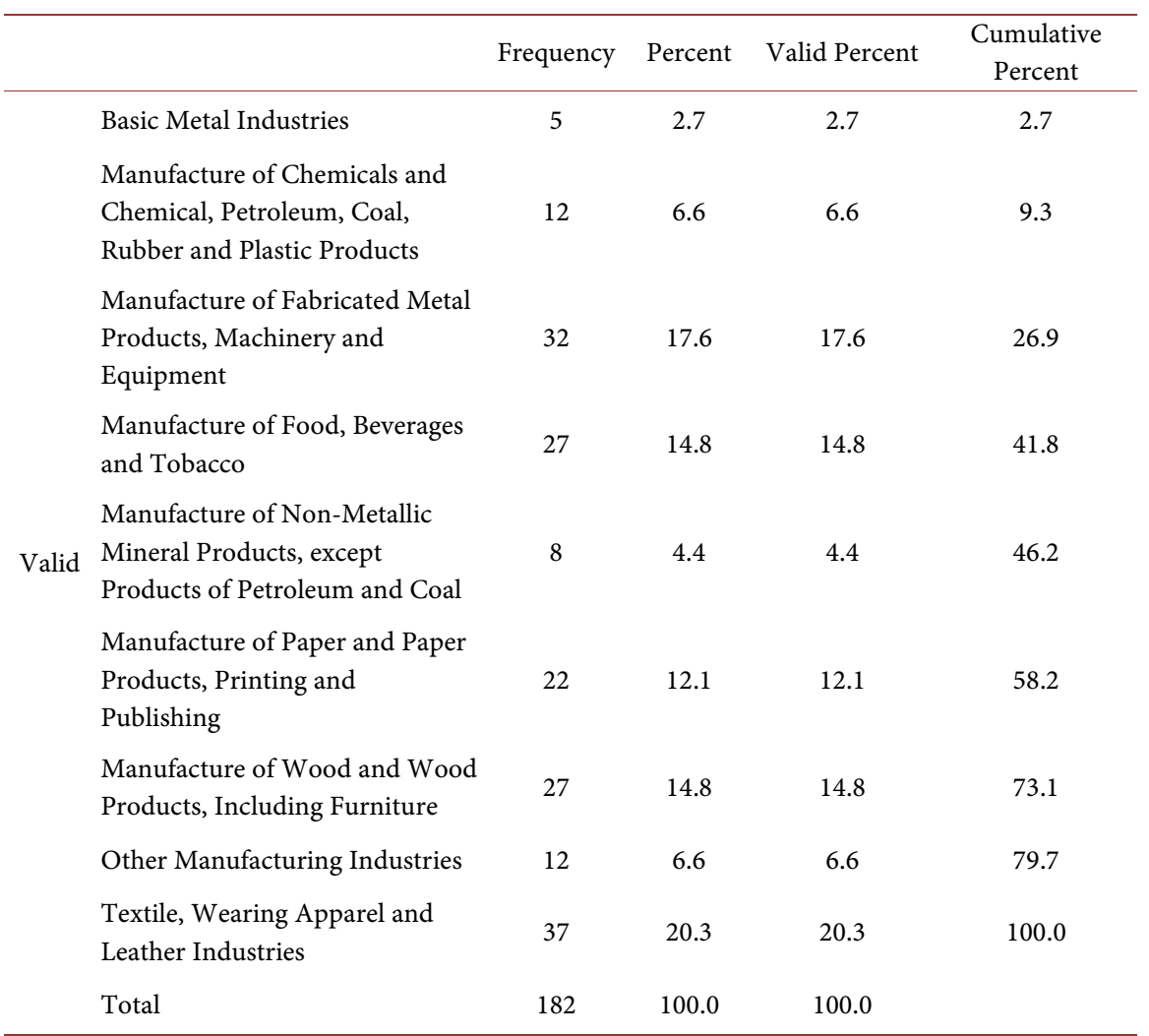




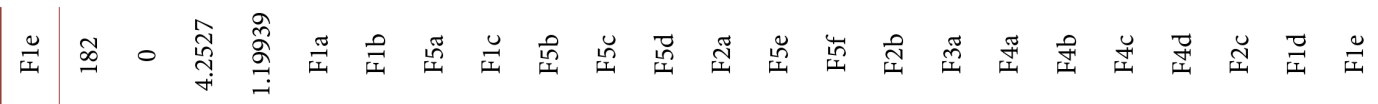

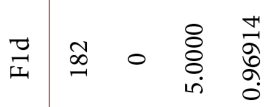

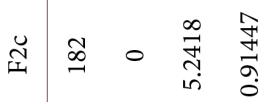

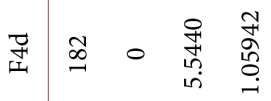

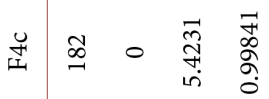

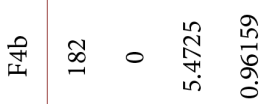

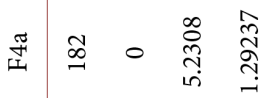

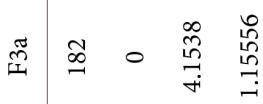

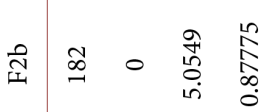

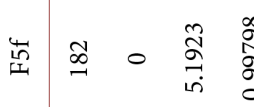

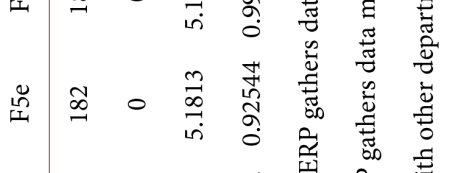

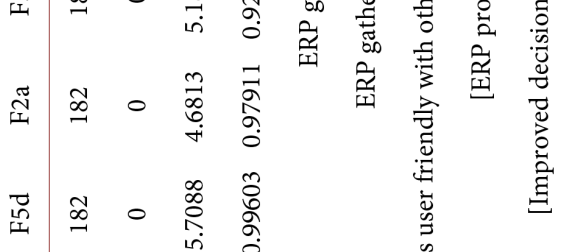

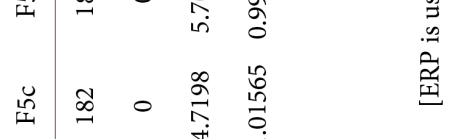

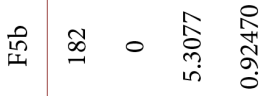

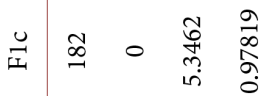

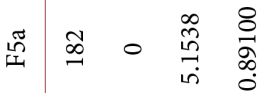

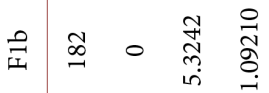

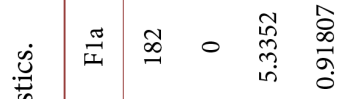

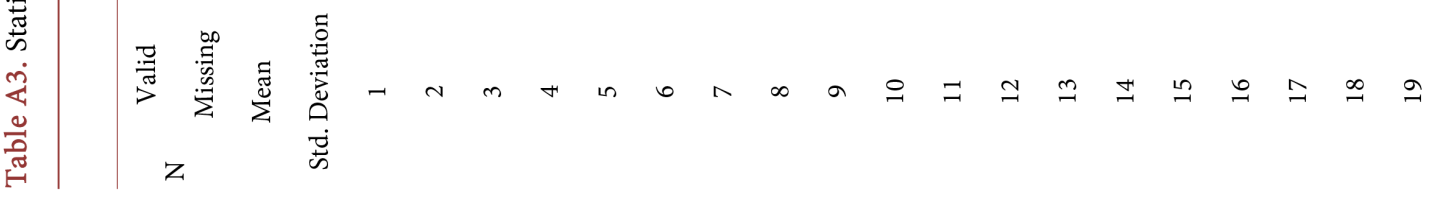

